\title{
Analysis of mechanical properties and distribution of deformation during the shear of polymer-fiber composites containing flame retardants (Rapid communication)
}

\author{
Rafał Oliwa ${ }^{1), *)}$, Katarzyna Bulanda ${ }^{1)}$, Mariusz Oleksy¹), Grzegorz Budzik ${ }^{2)}$, Sławomir Krauze ${ }^{3)}$ \\ DOI: dx.doi.org/10.14314/polimery.2020.5.7
}

\begin{abstract}
The work examined the effect of flame retardant addition to the epoxy resin powder matrix on the mechanical properties of composites reinforced with biaxal glass fabric. Two flame retardant systems were used to modify the epoxy resin: (1) melamine polyphosphate (MPP) and aluminum diethyl phosphinate (AlDPi); (2) ammonium polyphosphate (APP) and dipentaerythritol (DPE). The flame retardant content was $25 \mathrm{wt} \%$. In addition, individual compositions also contained $15 \mathrm{wt} \%$ of zinc borate (ZB). Tensile, bending and shear tests for the obtained composites were performed. Furthermore, using the digital image correlation method, an analysis of local strains on the sample surface during shear test was carried out. The obtained results indicate, that the amount and type of flame retardant affects the mechanical properties of the composites. Among the tested systems, the best results were obtained for a composite containing $18 \mathrm{wt} \%$ ammonium polyphosphate and $7 \mathrm{wt} \%$ dipentaerythritol. Compared to the reference sample, among others, the shear stress and shear modulus increased by 25.0 and 39.7\%, respectively. In turn, a clear deterioration of the tested parameters was observed in the case of a composite with a matrix containing $15 \mathrm{wt} \%$ of AlDPi, $10 \mathrm{wt} \%$ of MPP and $15 \mathrm{wt} \%$ of ZB, because, compared to unmodified composite, the flexural, tensile and shear stress were reduced by $50.9,53.5$ and $34.8 \%$, respectively.
\end{abstract}

Keywords: powder-epoxy resin, laminates, flame retardants, mechanical properties, digital image correlation.

\section{Analiza właściwości mechanicznych oraz rozkładu odkształceń w trakcie ścinania kompozytów polimerowo-włóknistych z dodatkiem uniepalniaczy}

Streszczenie: Zbadano wpływ dodatku uniepalniaczy: (1) poli(fosforanu melaminy) (MPP) i dietylofosfinianu glinu (AlDPi); (2) polifosforanu amonu (APP) i dipentaerytrytolu (DPE), o sumarycznym udziale w kompozycie 25\% mas., na właściwości mechaniczne kompozytów na osnowie proszkowej żywicy epoksydowej wzmocnionych biaxialną tkaniną szklaną. Poszczególne kompozycje zawierały dodatkowo $15 \%$ mas. boranu cynku (ZB). Oceniono wytrzymałość na rozciąganie, zginanie i ścinanie otrzymanych kompozytów. Z wykorzystaniem metody cyfrowej korelacji obrazu przeprowadzono też analizę odkształceń lokalnych na powierzchni próbek kompozytów w trakcie ścinania. Uzyskane wyniki wskazują, że zarówno ilość, jak i rodzaj dodanego uniepalniacza wpływają na właściwości mechaniczne kompozytów. Spośród zbadanych układów najlepsze wyniki wykazywał kompozyt zawierający $18 \%$ mas. polifosforanu amonu i $7 \%$ mas. dipentaerytrytolu. Stwierdzono, że, w porównaniu z próbką referencyjną, m.in. wytrzymałość na ścinanie oraz moduł ścinania zwiększyły się o, odpowiednio, 25 i 39,7\%. Zaobserwowano natomiast wyraźne pogorszenie badanych parametrów w wypadku kompozytu z osnową zawierającą 15\% mas. AlDPi, 10\% MPP oraz 15\% ZB, gdyż, w odniesieniu do kompozytu z niemodyfikowaną osnową, naprężenia zginające, rozciągające i ścinające zmniejszyły się o, odpowiednio, 50,9; 53,5; i 34,8\%.

Słowa kluczowe: proszkowa żywica epoksydowa, laminaty, uniepalniacze, właściwości mechaniczne, cyfrowa korelacja obrazu.

\footnotetext{
1) Rzeszow University of Technology, Faculty of Chemistry, al. Powstańców Warszawy 12, 35-959 Rzeszów, Poland.

2) Rzeszow University of Technology, Faculty of Mechanical Engineering and Aeronautics, al. Powstańców Warszawy 12, 35-959

Rzeszów, Poland.

3) SZTK TAPS Maciej Kowalski, Borowa 4, 94-247 Łódź, Poland.

*) Author for correspondence: oliwa@prz.edu.pl
} 
Due to the fact that composites are used in constructions that are exposed to high temperatures, an important issue is also the improvement of the fire retardant properties of materials. Not only flame retardants that reduce the flammability of composites, but also smoke reducing additives should be used as additions to their composition, which is important for the safety of people. Since the introduction of new directives severely limiting the use of halogenated compounds, the focus has been placed on flame retardants that are environmentally friendly. However, halogenated flame retardants still constitute a large part of the flame retardant market, but they are successively replaced by their halogen-free counterparts [1]. Currently, the aim is to choose such compositions of composites, so that they provide good fire retardant properties while maintaining the best mechanical properties [2]. The largest part of flame retardants are additive flame retardants such as aluminum or magnesium hydroxide, which are inexpensive, easy to manufacture and non-toxic. The disadvantage of these compounds is very high content of in their composition (minimum of 35-40 wt \%), in order to obtain fire retardant properties of composites, such as polyester composites [3, 4]. While composites not reinforced with fabrics are characterized by the same properties as unmodified resin, composites reinforced with glass fabric and containing at least 25 wt \% aluminum trihydroxide the polyester matrix show a decrease in compression and tensile strength by, 19 and 10\%, respectively [5]. A new group of flame retardants are intumescent systems, which are increasingly used because they show good flame retardant properties. Advantage of the flame retardants is their relatively low content required in a composition and lower emission of fumes and toxic gases during decomposition due to their action in both, the condensed and gas phases [6-9]. Interestingly, even a small addition of ammonium polyphosphate (APP) to the epoxy matrix causes a significant decrease in tensile and flexural strength $[8,10]$. However, the addition of APP up to $20 \mathrm{wt} \%$ to the epoxy matrix reinforced with glass fabric, doesn't result in a decrease, on the contrary it causes an increase $[8,10,11]$. Other phosphorus compounds [such as aluminum phosphinates (AlPi)], are also effective [12-14]. However, epoxy composites containing $\mathrm{AlPi}$ are characterized by the reduction of their mechanical properties [15], while there is no information on the mechanical properties of epoxy resin reinforced with glass fabrics and containing AlPi.

Therefore, the objective of the present study was to investigate the influence of type and content of phosphorus-based flame retardants such as phosphinates and polyphosphates on the mechanical properties of epoxybased composites with glass fabric reinforcement. Our previous work on the improvement of fire resistance of epoxy/glass laminates confirmed the effectiveness of aluminum phosphinates with melamine polyphosphates and ammonium polyphosphates with dipentaerythritol as flame-retardants [16] and a zinc borate as a smoke reducing agent [17]. The results presented in the following work are a continuation of the research conducted on the development of flame retardant glass-fiber reinforced composites with a matrix of powder epoxy resin used as the main structural elements of seats in public transport.

\section{EXPERIMENTAL PART}

\section{Materials}

One-component powder-epoxy resin A.S.SET Powder 01, commercial grade products of New Era Materials Plant, Poland.

Halogen-free commercial flame retardants: melamine polyphosphate (MPP), zinc borate (ZB), ammonium polyphosphate (APP), dipentaerythritol (DPE) all produced by WTH (GmbH, Germany) and aluminum diethyl phosphinate (AlDPi) produced by Clariant (Switzerland).

Glass woven roving fabric $\left(2 / 2,350 \mathrm{~g} / \mathrm{m}^{2}\right)$ manufactured by Rymatex Sp. z o.o. (Poland) was used as the main reinforcement. The powder resin was sieved with a mesh size of $0.25 \mathrm{~mm}$, other materials were used without further purification or modification.

\section{Preparation of epoxy compositions and glass fabric reinforced laminates}

The procedure of mixing flame retardants in powder-epoxy resin and the method of obtaining laminates from their matrices had been previously patented [18] and described in detail in our previous papers [16, 17]. According to the our previous results about fire resistant composites with reduced smoke emission, in this article the epoxy compositions containing two groups of flame retardants: (1) melamine polyphosphate (MPP) and aluminum diethyl phosphinate (AlDPi); (2) ammonium polyphosphate (APP) and dipentaerythritol (DPE) were prepared. In addition, the 15 wt \% of zinc borate (ZB) (which turned out to be a good smoke reducing agent), was added to each compositions [17]. The percent content of flame retardants in each mixture is shown in Table 1. The obtained compositions were used to prepare the six-

T a b l e 1. Powder-epoxy resin compositions with flame retardants

\begin{tabular}{c|c|c|c|c|c}
\hline \multirow{2}{*}{ Composition } & \multicolumn{5}{|c}{$\begin{array}{c}\text { Percentages of component of epoxy } \\
\text { compositions, \% }\end{array}$} \\
\cline { 2 - 6 } & AlDPi & MPP & ZB & APP & DPE \\
\hline AS0 & - & - & - & - & - \\
AS1 & 15 & 10 & - & - & - \\
AS2 & 15 & 10 & 15 & - & - \\
AS3 & - & - & - & 18 & 7 \\
AS4 & - & - & 15 & 18 & 7 \\
\hline
\end{tabular}


layer laminates with an approx. $50 \mathrm{wt} \%$ content of the reinforcement.

\section{Methods of testing}

Plate specimens $200 \mathrm{~mm} \times 25 \mathrm{~mm} \times 2.5 \mathrm{~mm}$ in size, were employed for tension test. Instron 5967 machine was used to perform tensile tests according to ISO 527-1. All specimens were tested at a speed of $2 \mathrm{~mm} / \mathrm{min}$.

The bending tests were performed according to EN ISO 14125, using the same tensile machine equipped with a three point bending rig. The vertical displacement speed of the rig during the test was $2 \mathrm{~mm} / \mathrm{min}$ and the supporting span length was fixed at $40 \mathrm{~mm}$. The specimens were $60 \mathrm{~mm}$ long, $15 \mathrm{~mm}$ wide and $2.5 \mathrm{~mm}$ thick.

V-notched rail shear test was performed according to ASTM D7078. The specimens were tested at a cross-head speed of $2 \mathrm{~mm} / \mathrm{min}$ using Instron 5967 machine equipped with digital image correlation system (Aramis, GOM, Germany) to determine the $\pm 45^{\circ}$ deformation. The procedure described in our previous publication was applied [19]. On the basis of the recorded images, the Kirchhoff module and major strain distribution on the surface of samples were determined.

The shear modulus of the composites was determined using the formula [20]:

$$
G=\frac{\tau_{2}-\tau_{1}}{\gamma_{2}-\gamma_{1}}
$$

where: $\tau_{1}$ - shear stress at shear strain, $\gamma_{1}=0.002[\mathrm{~mm} / \mathrm{mm}]$, $\tau_{2}$-shear stress at shear strain, $\gamma_{2}=0.005[\mathrm{~mm} / \mathrm{mm}]$.

The shear strain was calculated by the relationship

$$
\bar{\gamma}=\varepsilon_{45}-\varepsilon_{-45}[\mathrm{~mm} / \mathrm{mm}]
$$

where: $\varepsilon_{45^{\prime}} \varepsilon_{-45}$ are the deformations at an angle of $+45^{\circ}$ and $-45^{\circ}$ to the fiber direction, respectively.

\section{RESULTS AND DISCUSSION}

Based on the results summarized in Table 2, it was found that the addition of flame retardants to the epoxy matrix affects the tensile and flexural strength of laminates reinforced with glass fabric.
In addition, increasing the content of flame retardants enhanced this effect. The type of used flame retardants also had a significant impact on the change in the tested parameters. A greater decrease in the studied parameters was recorded for composites containing aluminum diethyl phosphinate and melamine polyphosphate, which have V0 class by UL94 [16]. The AS1 matrix composite containing 15 wt \% AlDPi and 10 wt \% MPP was characterized by a decrease in tensile strength and Young's modulus by 36.8 and $29.5 \%$, respectively, compared to the reference sample. Furthermore, the addition of $15 \mathrm{wt} \%$ of $\mathrm{ZB}$ results in reduce of the tested quantities by 26.4 and $9.2 \%$, respectively, compared to the AS1 composite. Similar relationships were observed during the bending test. The AS1 and AS2 composites characterized by a significant deterioration of flexural strength, by 266.9 and $347.8 \mathrm{MPa}$, respectively, compared to composite with unmodified matrix (flexural strength $=682.5 \mathrm{MPa}$ ). Such a significant decrease in bending strength is associated with delamination occurring, which is the main mechanism of destruction during the flexural test [21]. On the other hand, the AS2 composite stood out the smallest smoke emission intensity [17].

For composites containing ammonium polyphosphate and dipentaerythritol (which have only achieved V1 flammability class [16]), changes in mechanical properties were small, because the tensile strength and Young's modulus of AS3 sample decreased by 6.9 and $9.2 \%$ compared to AS0 composite, what is in accordance with literature data $[8,9]$. In turn, the addition of $15 \mathrm{wt} \%$ of $\mathrm{ZB}$ resulted in a reduction in tensile stress and Young's modulus of the AS4 composite. Despite this, the composite was characterized by higher values of the tested parameters compared to the AS2 composite, which contained only AlDPi and MPP. As in the case of tensile strength, composites containing APP and DPE are characterized by much higher values of flexural stress and elastic modulus compared to materials containing AIDPi and MPP. Despite this, the flexural stress and elastic modulus of AS3 composites were lower, by 17.6 and $11.8 \%$, respectively, compared to the reference sample, which partly overlaps with literature data - the addition of APP causes a slight decrease in strength but increases the stiffness of glass fiber composites [8, 11]. It may be associated with more difficult mixing of flame retardants with powder resin and wetting of the fabric

$\mathrm{T}$ a b l e 2. The results of mechanical properties of glass fabric reinforced laminates prepared using unmodified matrix and epoxy resin with flame retardants

\begin{tabular}{c|c|c|c|c|c|c|c|c}
\hline $\begin{array}{c}\text { Symbol of } \\
\text { sample }\end{array}$ & $\begin{array}{c}\text { Ultimate } \\
\text { tensile } \\
\text { strength } \\
\text { MPa }\end{array}$ & $\begin{array}{c}\text { Young } \\
\text { modulus } \\
\text { GPa }\end{array}$ & $\begin{array}{c}\text { Strain } \\
\%\end{array}$ & $\begin{array}{c}\text { Flexural } \\
\text { strength } \\
\text { MPa }\end{array}$ & $\begin{array}{c}\text { Flexural } \\
\text { modulus } \\
\text { GPa }\end{array}$ & $\begin{array}{c}\text { Strain } \\
\%\end{array}$ & $\begin{array}{c}\text { Shear } \\
\text { strength } \\
\text { MPa }\end{array}$ & $\begin{array}{c}\text { Shear } \\
\text { modulus } \\
\text { GPa }\end{array}$ \\
\hline AS0 & $443.6 \pm 7.9$ & $10.81 \pm 0.51$ & $5.5 \pm 0.1$ & $682.5 \pm 15.1$ & $20.2 \pm 0.8$ & $3.9 \pm 0.3$ & $47.9 \pm 3.6$ & $2.44 \pm 0.25$ \\
AS1 & $280.4 \pm 12.5$ & $7.62 \pm 0.53$ & $5.1 \pm 0.5$ & $415.6 \pm 14.6$ & $15.9 \pm 0.5$ & $2.5 \pm 0.4$ & $37.1 \pm 3.7$ & $2.34 \pm 0.62$ \\
AS2 & $206.4 \pm 14.5$ & $6.94 \pm 0.41$ & $5.2 \pm 0.1$ & $334.7 \pm 16.3$ & $13.8 \pm 0.4$ & $1.4 \pm 0.2$ & $31.2 \pm 4.3$ & $2.26 \pm 0.11$ \\
AS3 & $412.8 \pm 6.3$ & $9.82 \pm 0.67$ & $5.4 \pm 0.2$ & $561.8 \pm 19.4$ & $17.8 \pm 0.7$ & $3.3 \pm 0.3$ & $59.9 \pm 4.7$ & $3.41 \pm 0.58$ \\
AS4 & $356.4 \pm 9.3$ & $7.95 \pm 0.28$ & $5.3 \pm 0.1$ & $497.5 \pm 16.7$ & $17.2 \pm 0.8$ & $2.8 \pm 0.4$ & $51.8 \pm 2.4$ & $3.23 \pm 0.41$ \\
\hline
\end{tabular}




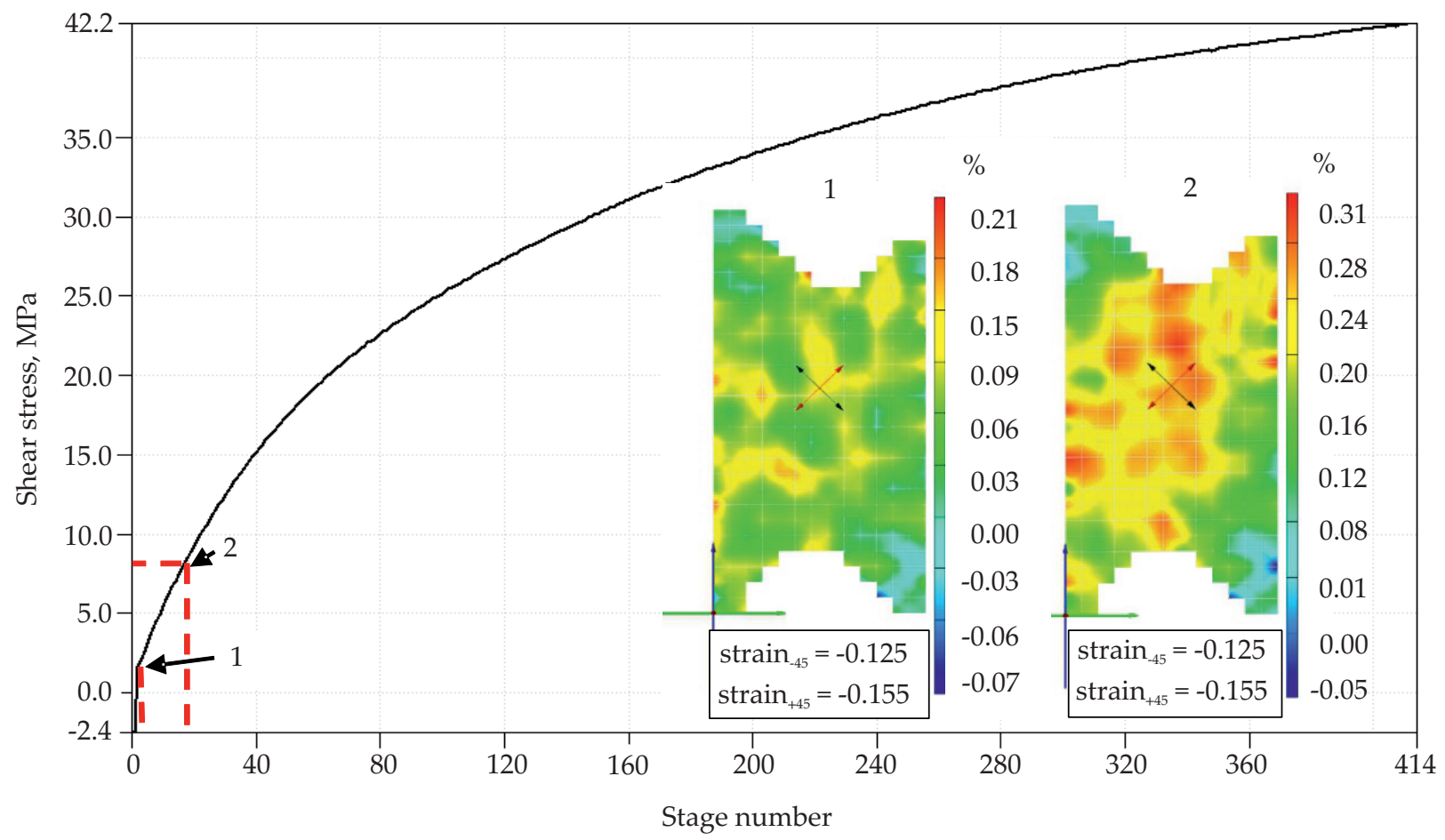

Fig. 1. Shear stress change with analysis of strain fields for two measuring points to determine the shear modulus

during composite compression technology compared to traditional liquid resins.

Analysis of the shear strength results indicates that the addition of AlDPi and MPP to the epoxy matrix causes a decrease in shear stress of AS1 and AS2 composites, which corresponds with the other results of mechanical properties. Interestingly, composites containing APP and DPE are characterized by a much higher, by $25 \%$, shear strength compared to the composite AS0 (shear stress $=47.9 \mathrm{MPa}$ ). Furthermore, the addition of zinc borate only slightly reduced the shear strength, as a result of which the shear stress of the AS4 composite was $51.8 \mathrm{MPa}$, which was a change of $8.1 \%$ relative to AS0. As a result of the study, the Kirchhoff module was also determined. The data needed for its calculation (shear stress and deformation) were determined using a graph (Fig. 1.) and strain analysis in the $\pm 45^{\circ}$ direction, which was determined on the basis of the digital image correlation for the two measuring points shown in Fig. 1.

The obtained results of the Kirchhoff module are consistent with the shear stress values, because again composites containing AlDPi and MPP are characterized by a smaller value of the module compared to the refer- ence sample. However, the decrease recorded is small, at $4.1 \%$. In turn, the shear modulus of AS3 and AS4 composites increased by 0.97 and $0.79 \mathrm{MPa}$, which constituted a change of 39.7 and $32.3 \%$, respectively, compared to the unmodified composite.

Based on the recorded images, an analysis of the major strain (blue line) and strains in the $\pm 45^{\circ}$ direction (black and red line) were carried out (Fig. 2). It showed, that composites with higher shear strength and Kirchhoff modulus were characterized by higher deformations. As a result, the AS3 and AS4 matrix composites were characterized by major strains in the range of $0.42-5.48 \%$ and $0.01-4.17 \%$, respectively (Figs. $2 \mathrm{~d}, 2 \mathrm{e}$ ). In turn, the major deformations of the AS1 and AS2 matrix composites were in the range of $0.23-3.54 \%$ and $0.07-2.26 \%$ (Figs. $2 b, 2 c$ ). In the case of a sample with unmodified matrix, the major strain were at the level of $0.16-3.75 \%$ (Fig. 2a). Similar results were observed for the curves showing the deformations in the +45 and $-45^{\circ}$ direction. It was found, that the highest strain in the $\pm 45^{\circ}$ direction had AS3 composite and the smallest - had AS2 composites. As a result, AS2 and AS3 composites were characterized by shear strain at maximum load at the level of 9.0 and $2.5 \%$, respectively. 


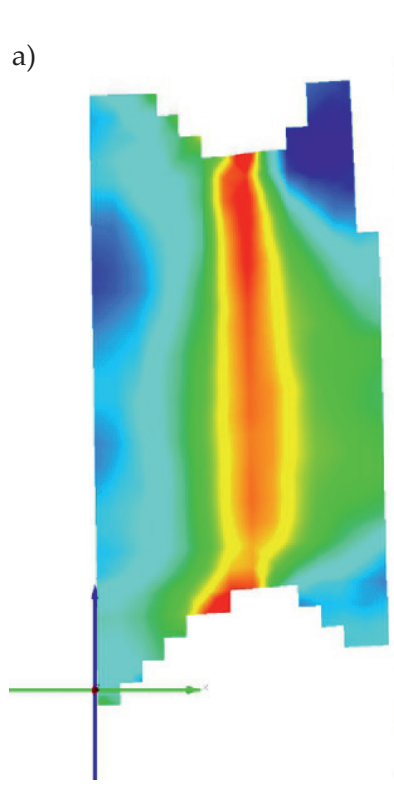

$\%$

b)

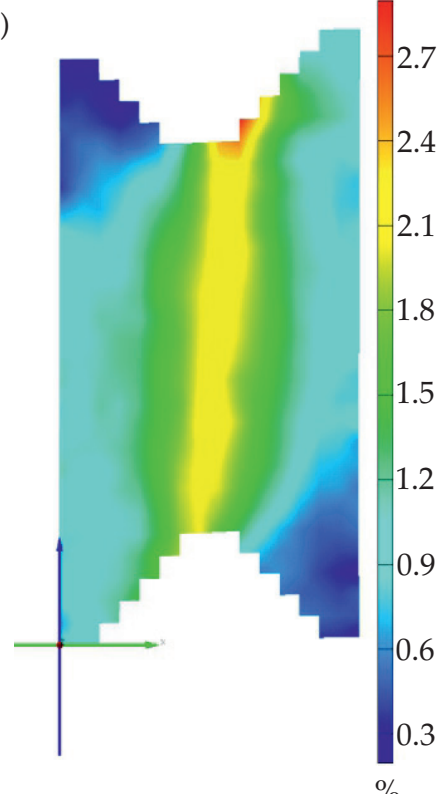

c)

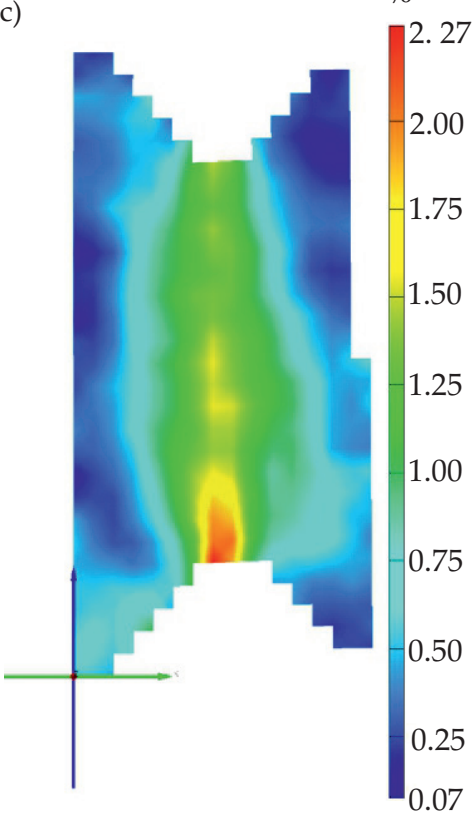

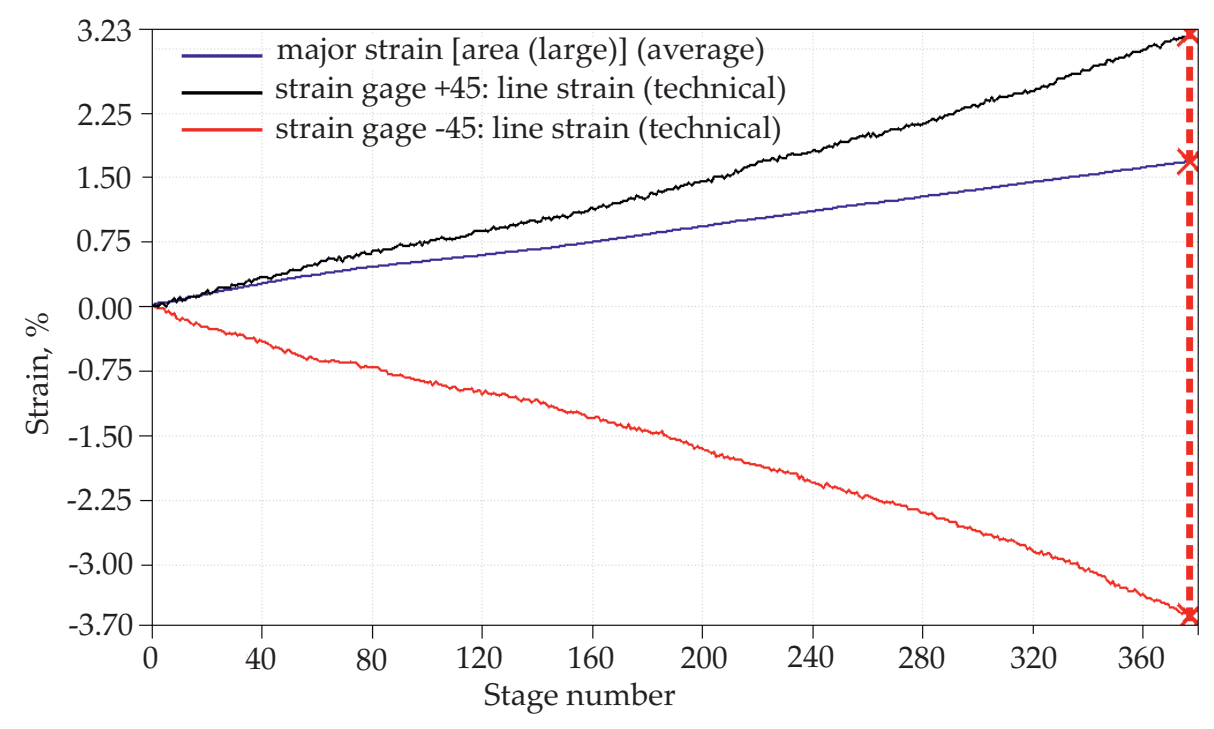

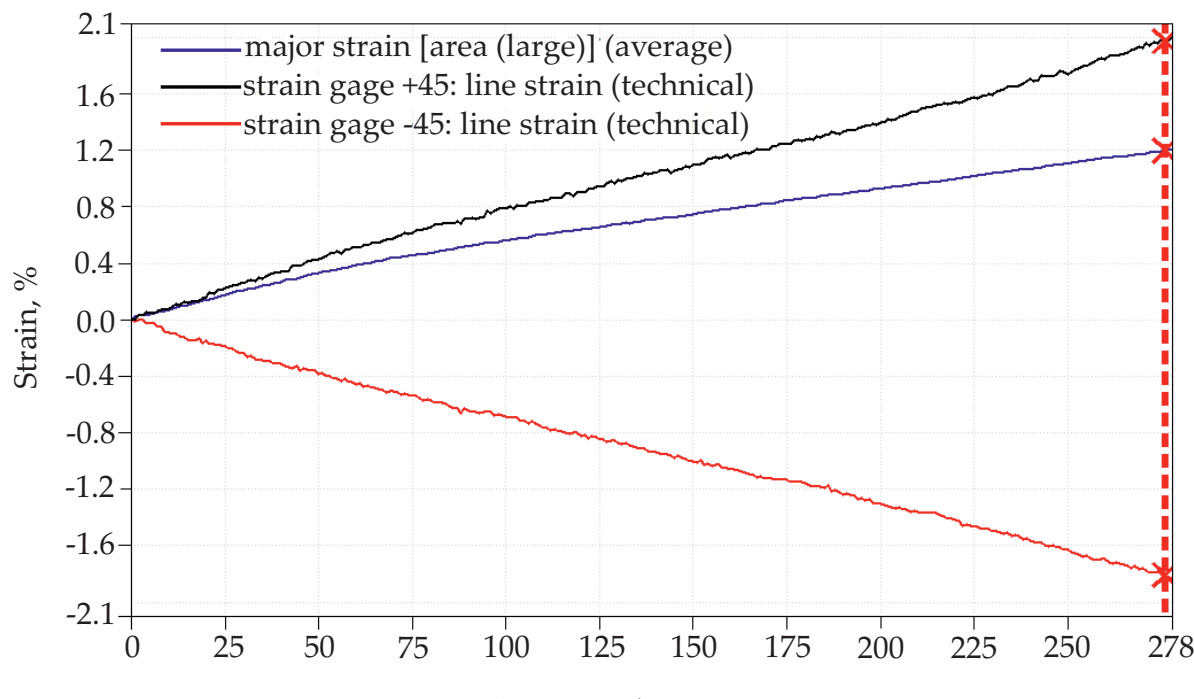

Stage number

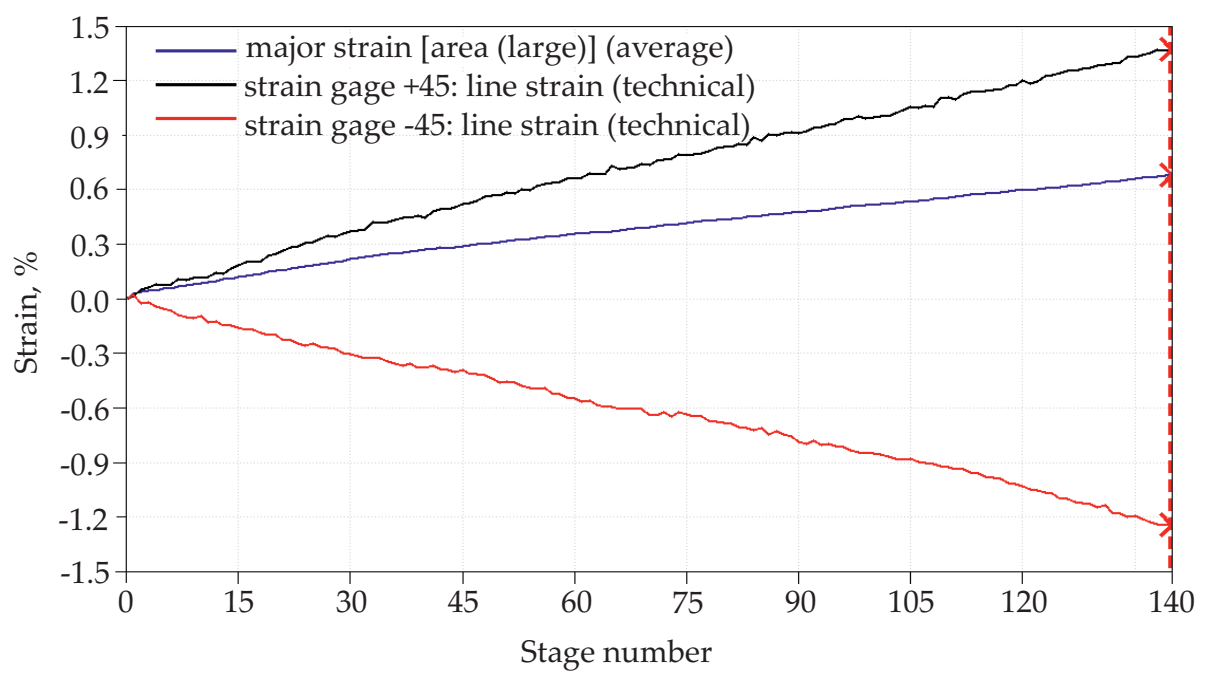



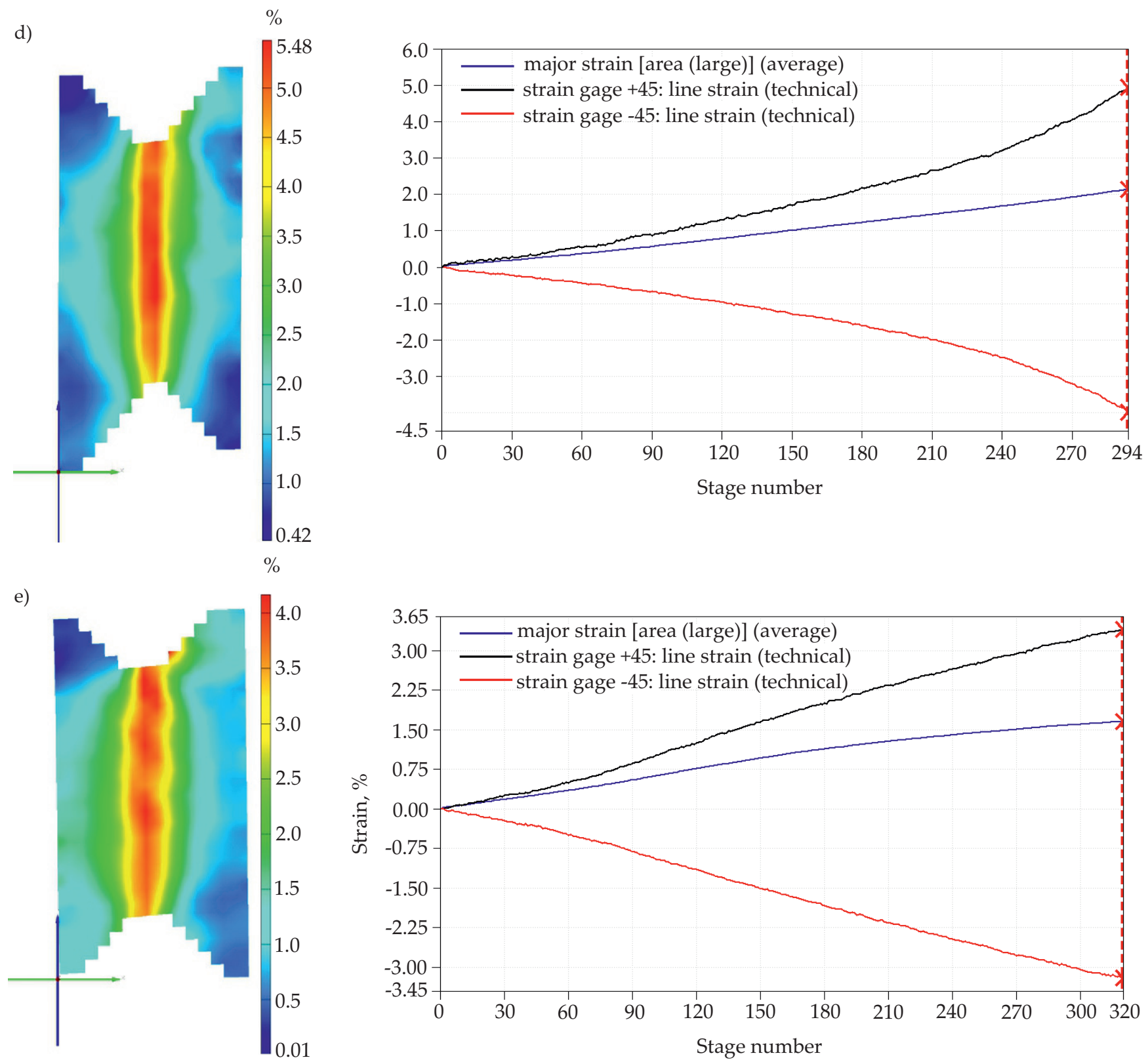

Fig. 2. Diagrams of major strain under the maximum force on the sample surface (left) and the strain-stage number relationship (right) of the composite: a) AS0, b) AS1, c) AS2, d) AS3, e) AS4

\section{CONCLUSIONS}

The effect of flame retardant addition to powder-epoxy resin on the mechanical properties of glass fiber reinforced composites was investigated. Tensile, bending and shear tests were carried out. Based on the obtained results, it was found that the addition of ammonium polyphosphate and dipentaerythritol had the least impact on the mechanical properties of the composites. These materials were characterized by tensile strength at the level of the reference sample and the smallest decrease by 17.6 and $11.8 \%$ of flexural strength and elastic modulus, respec- tively. Interestingly, shear strength and shear modulus increased significantly, which resulted in high values of shear and main deformations obtained during the analysis of local deformation fields by digital image correlation. In turn, a clear decrease in mechanical properties was observed for composites with the addition of AlDPi and MPP, which can be mainly influenced by AIDPi, as it belongs to phosphate flame retardants from the phosphinate group, while APP and MPP belongs to the polyphosphates group. On the other hand, AIDPi and MPP showed to be more effective flame retardants than APP and DPE, as composites with their addition were char- 
acterized by V0 and V1 flammability class, respectively $[16,17]$. Regardless of the type of flame retardants, the additional introduction of ZB, which suppresses smoke, causes another decrease in mechanical properties.

Financial support from Structural Funds in the Operational Program - Innovative Economy, European Regional Development Fund - No. POIR.01.01.01-00-0158/16, "Industrial and development research into the design and production of prototypes for optional type series of innovative seats to be used as furnishing in public means of rail transport".

\section{REFERENCES}

[1] Rakotomalala M., Wagner S., Döring M.: Materials 2010, 3, 4300.

https://doi.org/10.3390/ma3084300

[2] Perret B., Schartel B., StöB K. et al.: Macromolecular Materials and Engineering 2011, 296, 14.

https://doi.org/10.1002/mame.201000242

[3] Gunes O.C., Gomek R., Tamar A. et al.: Arabian Journal for Science and Engineering 2018, 43, 6211. https://doi.org/10.1007/s13369-018-3397-6

[4] Tang H., Zhou X., Liu X.: Procedia Engineering 2013, 52, 336. https://doi.org/10.1016/j.proeng.2013.02.150

[5] Petersen M.R., Chen A., Roll M. et al.: Composites Part B 2015, 78, 109.

https://doi.org/10.1016/j.compositesb.2015.03.071

[6] Kużdżał E., Cichy B., Kicko-Walczak E., Rymarz G.: Journal of Applied Polymer Science 2017, 134 (2). https://doi.org/10.1002/app.44371

[7] Das O., Bhattacharyya D., Hui D., Lau K.T.: Composites Part B: Engineering 2016, 106, 120. https://doi.org/10.1016/j.compositesb.2016.09.020

[8] Rajaei M., Wang D.-Y., Bhattacharyya D.: Composites Part B: Engineering 2017, 113, 381. https://doi.org/10.1016/j.compositesb.2017.01.039

[9] Matykiewicz D., Przybyszewski B., Stanik R., Czulak A.: Composites Part B: Engineering 2017, 108, 224. https://doi.org/10.1016/j.compositesb.2016.10.003

[10] Liu L., Zhang Y., Li L. Wang Z.: Polymers for Advanced Technologies 2011, 22, 2403. https://doi.org/10.1002/pat.1776

[11] Patrick Lim W.K., Mariatti M., Chow W.S., Mar K.T.: Composites Part B: Engineering 2012, 43, 124.

https://doi.org/10.1016/j.compositesb.2011.11.013

[12] Hu Q., Peng P., Peng S. et al.: Journal of Thermal Analysis and Calorimetry 2017, 128, 201. https://doi.org/10.1007/s10973-016-5907-7

[13] Liu L., Yang Y., Ma J. et al.: Journal of Applied Polymer Science 2017, 134, 45445 https://doi.org/10.1002/app.45445

[14] Yaun Y., Yu B., Shi Y. et al.: Polymers 2020, 12, 64. https://doi.org/10.3390/polym12010064

[15] Wang Y., Zhang L., Yang Y., Cai X.: Journal of Thermal Analysis and Calorimetry 2015, 3, 122. https://doi.org/10.1007/s10973-015-4875-7

[16] Oliwa R., Oleksy M., Czech-Polak J. et al.: Journal of Fire Sciences 2019, 37, 155. https://doi.org/10.1177/0734904119831211

[17] Oliwa R., Oleksy M., Oliwa J. et al.: Polimery 2019, 64, 290. https://doi.org/10.14314/polimery.2019.4.7

[18] PL Pat. Appl. 426498 (2018).

[19] Oliwa R.: Przeglad Mechaniczny. Pomiary 2018, 7-8, 17.

[20] Adams D.O., Moriarty J.M., Gallegos A.M.: “Development and Evaluation of the V-Notched Rail Shear Test for Composite Laminates", Office of Aviation Research, Washington, D.C. 20591, 2003.

[21] Bradley W.L.: Key Engineering Materials 1989, 37, 161. https://doi.org/10.4028/www.scientific.net/ KEM.37.161

Received 7 II 2020.

\section{Rapid Communications}

Przypominamy P.T. Autorom, że publikujemy artykuły typu Rapid Communications. Prace oryginalne wyłącznie w języku angielskim o objętości 4-5 stron maszynopisu z podwójną interlinią (plus ewentualnie 2-3 rysunki lub 1-2 tabele), którym umożliwiamy szybką ścieżkę druku (ok. 4 miesiące od chwili ich otrzymania przez Redakcję). Artykuł należy przygotować wg wytycznych zamieszczonych we wskazówkach dla Autorów. 